\title{
DIVORCED SERVICEMEN'S CHILDREN AND WAR CONDITIONS
}

\author{
JAY L. BenedrCT*
}

Observations over a long period prior to the present war warrant the conclusion that in the absence of war conditions the problems pertaining to divorced servicemen's children do not differ materially from the problems of children of other divorced parents. The number of such cases is quite small due to the limited size of peace-time military and naval establishments and to marriage not being encouraged among the enlisted personnel. The custody of the children is generally with the mother or with some relative of the father, rarely with the father. The decreed payments for support are necessarily small in conformity with the low rates of peacetime service pay. The accomplishment of the payments decreed is relatively certain due to the father being in service. Aside from these minor factors the children fare the same and suffer the same handicaps as do the general run of children of divorced parents. It is necessary to direct our attention to war conditions if we are to find problems of greater significance pertaining to an appreciable number of children of divorced servicemen.

\section{War Disturbance of Family Life}

An appreciation of the general pattern of social and family conditions in which problems arise is important to their consideration. The family conditions brought about by the war are quite varied but do not form any outstanding pattern bearing upon the problems of children of divorced servicemen. Superficially it sometimes appears that due to the war we have a pronounced disturbance of the very roots of family life. However, it would be going too far to accept fully the frequently expressed view that war destroys or seriously weakens the warp and woof of the social fabric of the nation. There are of necessity many family separations and dislocations incident to military and naval service and the economic changes that take place in support of the war effort. These separations and dislocations multiply and complicate the problems of family relationship, and of welfare and support of the families of servicemen. They also cause a wide range of legal and social aspects of the problems and their solutions. There is some tendency to transfer to the national government, in whole or in part, family financial support of a man called into service and, as a corollary, there is some lessening of the man's sense of responsibility. There is some loosening and some destruction of family ties, especially those that

- B.S., U. S. Military Academy, 1904. Major General, U. S. Army. President, War Department Dependency Board. The views expressed herein are the personal views of the writer and are not to be regarded as those of the War Department. 
never were very firm. There is some slipping in moral standards-attention being drawn to flagrant cases of marital discord, or worse. There has been considerable increase in the desire for divorce (but not in its accomplishment) in order to escape compulsory pay deductions for the support of wives that servicemen object to supporting. Only infrequently do their objections extend to supporting children by an estranged wife, in fact they frequently endeavor to get the children away from the wife and into what they consider a better environment. However, all of the more serious manifestations of social disorder are more conspicuous than numerous; the most that can be said of them is that they indicate tendencies. A broad view does not disclose that due to war there has been a serious breakdown in family relations, in appreciation of family responsibilities, or in moral standards. In fact we have constant indications that separations incident to the service of the nation, and other circumstances of war, have in the long run considerable effect in strengthening family ties and the threads of the social fabric.

Such consideration as is herein given to social and family problems pertaining to servicemen is not predicated upon any assumption that they arise through deleterious abnormalities in the social order or through any general deterioration of standards or conduct brought about by war. On the other hand it is recognized that social problems are influenced by physical separations and dislocations, by measures of government support for families of servicemen, and by certain human weaknesses always with us that find greater freedom of expression under war conditions. Also, those problems arising through the marital relationship or its impairment are affected by the number, haste and purposes of war-time marriages.

A slight digression may prove worth while to present a factor related to the general social situation which is all too frequently unappreciated. In every war psychology is important. In the present struggle every participant is waging some form of psychological warfare. To directly or indirectly create doubt in the mind of the soldier as to conditions at home, and particularly as to the conduct and fidelity of wives, is not a new trick. It has met with some success. Unfortunately, there are some well-meaning reformers, meddlers and purveyors of "news" that unwittingly help the enemy in sowing doubt and causing discord. There is also a tendency toward over-emphasis of the few cases of a glaring nature and of measures proposed to remedy them, thus creating an erroneous impression that conditions are far worse than they actually are. There is always the danger that proposals bearing on the problem may be of such nature that in seeking to help a few a false perspective is created and we seriously injure the morale of the whole service, thus doing what the enemy intends to do by his insidious propaganda. This thought has particular application to proposals to amend the laws governing allowances to families of servicemen.

\section{The Nature of the Problems}

Getting on to our subject, we may advantageously place the children of divorced servicemen in two categories; those of men divorced prior to entry into the service, 
and those of men divorced while they are in service. The second category breaks down further according to whether or not the basic cause or inception of divorce antedates entry into service, but, insofar as the effects upon the children are concerned, this secondary breakdown is of no moment as such effects flow from decrees granted while the man is in service.

In the category of divorces accomplished during service the effects upon children do not differ greatly from those flowing from other divorces. Except in a few cases where the wife's misconduct or unfitness is disclosed custody of the children is generally given to the wife. The father being in service and temporarily without a home, the hazards of war, and the possibility of the father not returning are also factors in awarding custody to the wife in some cases in which it might not be done otherwise. In the exceptional cases in which the serviceman is given the custody he sometimes has difficulty in providing or arranging a suitable home for the child or children and the problem of custodial care becomes acute. Unfortunately, the solution of the problem does not always get the attention it deserves, or there is little choice, and the child may be placed under circumstances not favorable to its welfare. Children involved in divorce, and particularly the children of unfit mothers, should, in their interests and those of society, be assured custodial care of a high order. Such an obligation assumes national and vital importance to the peace of mind and efficiency of the fighting man while he is engaged in military service in time of war.

The support for a serviceman's child provided in a war-time divorce decree is generally similar to that provided in other cases arising in the same jurisdiction. If the custody of the child goes to the wife the total amount awarded for the child's support may be somewhat affected by well-intentioned sympathy and leniency towards the man in service. If custody of the child does not go to the wife the greater sympathy for the soldier-husband and the disinclination to divert his military pay may also affect somewhat the amount decreed for support of the child. However, inadequacy of the support decreed is more frequently due to custom than to such special considerations. It has been reported that in some instances giving judicial consideration to the dependents' allowances provided during war by Federal law has had the effect of reducing the decreed amounts below what they would otherwise be. On the other hand the effect of such consideration is sometimes a greater award for support than would otherwise be made. These expedients, like others, take a rather short-range view and may in the long run work to the disadvantage of those they are intended to help.

An interesting case is one in which the court wishing to be certain that the wife receives for herself and two children the full maximum family allowances provided by the Servicemen's Dependents Allowance Act ${ }^{1}$ for a divorced wife and two children ( $\$ 42$ plus $\$ 30$ plus $\$ 20$; total $\$ 92$ ) provides in the decree for an award of $\$ 92$ per month, which is considerably greater than the usual awards in many jurisdictions.

${ }^{1} 56$ StAт. $38 x$ (1942), 56 SтAт. 747 (1942), 57 STAт. 577 (1943), 37 U. S. C. \$8201-221 (Supp. III, 1941-1943). 
The family allowance law requires that allowances to children with divorced mothers be uninfluenced by a court award, but that the allowance to the divorced wife not exceed the amount decreed by the court for her support. It is necessary, in order to comply with the law, to break down a total awarded by the court, but not subdivided by it, to determine the wife's portion. A joint regulation for so doing has been prescribed for the Army and Navy to the effect that when the award covers a wife and two children the wife's portion shall be deemed $40 \%$ of the total. Applying this in the case of the $\$ 92$ award gives the wife $\$ 36.80$ per month-the children's portion of $\$ 50$ being unaffected. Hence the court fails in such a case, to the extent of $\$ 5.20$, in assuring the divorced wife the authorized maximum allowance of $\$ 42$ per month. This would not have been true had the decree specified $\$ 42$ (or more) as being the portion of the award for the wife's support. However, in this particular case not even the $\$ 36.80$ is paid monthly to the divorced wife. The court, for reasons unknown, stipulates that the total amount awarded be paid to the wife for support of the children. The unfortunate effect of such a stipulation, insofar as application of the family allowance law is concerned, is to reduce the wife's alimony to zero and hence to reduce her family allowance to zero and to cause a monthly check of only $\$ 50$ to be sent to her as payee for the children. Somewhat similar action which defeats the intent of the court happens in states granting interlocutory decrees, due to erroneous belief that the wife is entitled to full family allowance for herself until a final decree is entered.

A broad consideration of all types of cases arising through divorce granted while a man is in service leads to a conclusion that support for a child or children may be somewhat curtailed and the custodial care somewhat impaired by the circumstances of the father being a serviceman. Corrective action for such situations by modification of decree, when the father leaves the service and faces difficulties of economic and social readjustment, is not to be relied upon; hence any discriminatory effects of war-time divorce on children of servicemen in comparison with other children may be more or less permanent. The least that should be done is to eliminate, so far as practicable, in ordering support any consideration of the temporary status of the father being in service and of the war-time family allowance system.

An exceptional class of cases in which our system permits a severe hardship to be imposed upon the family of a serviceman are those in which he obtains a decree of divorce by substituted service and without any actual notice to his wife. Needless to say such decrees do not make provision for support for divorced wife and generally make none for the children. Such a divorced wife is usually unable by reason of reduced finances and of location to take action to have the decree set aside. Generally, the only recourse that the family may have is to the family allowance law. As the decree awards nothing there can be no family allowance paid to the wife. It is a fortunate circumstance in such cases that family allowances to the children are payable without the consent of the serviceman and without limitation by the court decree. Except for this circumstance both the wife and children would, as a result 
of an action in which the wife had no opportunity to be heard in the interests of herself or children, be completely without support. A general result that may flow from the granting of divorces under such circumstances is merely temporarily allayed for the children but in the administration of the family allowance law there is no relief for the divorced wife. In many such cases a family allowance application for a new wife is received.

\section{The Problens of the Illegitimate Child}

It may not be out of line to pass from consideration of servicemen's children where there has been an end of the marital status by divorce to consideration of those where the marital status is and has been absent, that is, the illegitimate children. The welfare and support of such children is equally a matter of concern, particularly those born, or becoming the subjects of support, while the man is in service. In many training areas and theaters where troops are stationed illegitimate children of servicemen come up for consideration. When these children remain with the mother, there is no problem of custody but only the problem of support. The same considerations that have been mentioned as tending to curtail the support decreed for children in cases of divorce of servicemen are operative in support orders and a further effect may flow from the view taken as to the social aspects. Inadequacies in amounts ordered for support are for the time being of no effect in cases in which any support is judicially decreed, or in which the parenthood is judicially decreed, or in which fatherhood is acknowledged by the serviceman, and the family allowance law comes into play. The family allowance for the illegitimate child is granted either upon the serviceman's application or upon an application made on behalf of the child. The amount of the family allowance is the same as provided by law for any other child and is not influenced by any lesser or greater amount awarded by a court decree. Thus during the life of the family allowance law the illegitimate child is as well provided for as any other child of the serviceman.

The provisions of law governing family allowances for illegitimate children have developed some interesting situations. In some instances recent inductees and men of some service have been acknowledging with alacrity numerous illegitimate children for whom either the man or the mother applies for family allowance. The scale, there being no wife, is $\$ 42$ for one child and $\$ 20$ for each additional child. If there is a wife these figures become $\$ 30$ and $\$ 20$ respectively. Some protests are received that the granting of such allowances, which are deemed too liberal in some sections, produces ill effects from an economic standpoint, inasmuch as they may, in the aggregate, cause considerable useful and needed labor of women and children to be lost. TThe underlying principle of these protests is worthy of consideration, particularly in view of our national production effort in prosecution of the war; however, it is not contemplated to now engage upon a discussion of that principle other than to state that it received the consideration of Congress in enacting the law. Those cases in which the man asks family allowances for a wife and for 
illegitimate children, and also those in which there is already an allowance to the wife in effect and he adds some illegitimate children, require careful consideration. This is particularly true when the serviceman designates the wife as the payee for all of the allowances and there are court decrees awarding nominal sums for support of the children. Investigation sometimes develops that the children are actually living with their own mother to whom the current wife is transmitting considerably less than the allowance she receives for the children's support. However, in cases in which the amount eventually applied to the support of illegitimate children is considerably less than the family allowance granted for them there may be no new hardship visited upon the children who probably never before had either acknowledgment or support from the father. Nevertheless, a redesignation of the mother as the payee in such cases is in order, in an effort to have the full amount being paid actually applied to the support of the children on whose account it is granted. In the complications of family allowance administration there have been similar cases in which the children were with a former wife divorced and a current wife was designated by the soldier as payee.

Generally speaking the principal administrative problem relative to illegitimate children is to assure against irregular over-loading of family allowance applications with them. The temptation is great. Illegitimate children may be easily established for family allowance purposes, all that is essential being an acknowledgment in writing. All children, legitimate or otherwise, fall-in the classification of Class A dependents and the deductions from the soldier's pay is $\$ 22$ per month whether he has one or a dozen such dependents drawing family allowances. The deduction is only $\$ 5$ more if there are also Class $B$ dependents (parents, brothers and sisters). An example of multiple allowances is a case in which at a cost of $\$ 27$ per month to the serviceman allowances were granted for a wife, four children, two parents and a divorced wife. In another case allowances were granted for a wife, two children, two parents and three sisters. At a cost to the serviceman of only \$22 per month allowances have been granted for a wife and nine children in one case and for eight children in another case, some being illegitimate children. However, modification of the family allowance schedules for the dependents of the serviceman is not suggested. Irregularities can be handled by investigation and elimination of unauthorized dependents, whether they be alleged illegitimate children or spurious wives.

There have been interesting cases abroad of illegitimate children of our servicemen. One case of quadruplets (three of them lived), acknowledged by a United States soldier in England has received considerable publicity and caused discussion of the propriety of any support being provided by this government in such a case. The soldier himself applied for the family allowances for the three children and as all conditions of the law were fulfilled there was, of course, no ground for denying him and his dependents the benefits of the law. In such cases, as in others, the welfare of children is a primary consideration and would be defeated if the alleged 
social offense involved were permitted to influence the payment of allowances. International comity must also be considered. We may not with propriety differentiate in the treatment of illegitimate children of our servicemen born abroad to nationals of foreign countries, and those born in our own country. If, as some persons contend, the alleged social offense is to be a bar to allowances for illegitimate children we must begin the change at home rather than to start it abroad, with the implication that the blame for a birth abroad rests entirely upon the mother. Such release of the soldier from any pecuniary responsibility would be most unwise. We should meticulously regulate the conduct of our soldiers in allied countries, punish their misdoings, and apply impartially our laws for support of their dependents, even though such dependents be foreign wives or illegitimate children born to foreign wives.

The alleged requirements of international comity in relation to allowances for dependents of our servicemen abroad have taken some unusual turns. Representations were made in more than one instance that the application of our schedules of allowances was harmful to economic conditions in some localities. Wives, children and illegitimate children of our servicemen were represented as receiving sums which according to local standards were excessive, with inferences that feminine activity was being directed toward the acquisition of soldier husbands and fathers. In one instance there was contention (but not of foreign origin) that it was against international comity for the United States to be making payments to or for illegitimate children in excess of amounts customarily fixed by the courts of the foreign country. The amount so fixed is controlled by custom, there being no contention of its adequacy for the child's support-in fact, there are indications that the amounts have an eye to class and ability to pay rather than to adequacy. The disregard of local custom and decree was represented as placing American fatherhood at a premium and encouraging illegitimacy. These various inferences did not, however, come directly from the people of the locality and there were no indications of any very serious situation developing. On the contrary it seemed not impossible that the basic dissatisfaction was on the part of our serviceman who suffered a $\$ 22$ per month deduction from his pay for support of an illegitimate child, whereas a payment of only about ten shillings a week was imposed upon a local father of an illegitimate child. Whatever the merits of the various views and circumstances a reasonable adjustment fulfilling all requirements has been made. There is adherence to the schedule of family allowance payments established by United States law and to the corresponding deductions from the pay of the serviceman; there is adherence to the principle of giving no effect to court orders. In general the allowance is administered just as in a domestic case. However in the designation of the payee some local court officer or other official may be designated and the monthly allowances disbursed locally for the child are thus locally controlled. Any excess over the monthly disbursements accrues for future support of the child. This avoids any discrimination and any subordination to foreign 
courts and looks beyond immediate support to the future when there will be no family allowance payments and possibly no direct payments by the father.

Whether the soldier-father of an illegitimate child is married or unmarried makes little difference in the support provided in the application of the family allowance law. The schedule of allowances is $\$ 42$ for one child and $\$ 20$ for each additional child if there is no lawful wife; the schedule is $\$ 30$ for one child and $\$ 20$ for each additional child if there is a wife receiving family allowance. All of the man's children, regardless of their motherhood or custody, are considered as one group for determination of the allowances payable. However, to meet various conditions and combinations that arise, the head of the department is authorized to distribute the aggregate amount payable for the group of children equally among the members, or otherwise.

\section{Where the Divorce Preceded the Induction}

We have yet to consider the effects of war conditions upon the important category of children of servicemen divorced prior to induction into the armed forces in time of war. In these cases the decree, with its provisions for the children, has been awarded in accordance with pre-war practices and circumstances and generally without anticipation of the father being called into service. Our interest is primarily to measure the general suitability of such decrees and arrangements to meet conditions of both peace and war. While legal procedures are not designed primarily to meet war conditions, they may at least give consideration to any ill effects of court determinations that may be caused or aggravated by the father being called into service. The family being the basic and indispensable unit of our civilized society we seek in every way to protect it and guard it against social ills. In recognition of this principle and of the necessity of fighting to preserve our brand of society, our obligation of protecting the family clearly extends to adequate protection of the children of men who must do that fighting. Insofar as is practicable this protection might well be developed in anticipation of war without reliance upon changes when war comes. The cases in which there has been any modification brought about by war of prior decrees as they affect the children of divorced servicemen, are rare.

In analyzing the pre-war divorce cases there are two main factors for consideration; first, custody, and second, support. Custody is used in the sense of not merely legal status but as including responsibilities pertaining to the development, environment, guidance and opportunity of the child whose custody is awarded. It is assumed the awarding of custody of children is generally on the basis of what is best for the child, but it cannot, of course, be entirely independent of the support factor. Custody should not be unduly influenced by such matters as the fault or guilt underlying the divorce. For purposes of this discussion we shall assume custody to have been satisfactorily awarded and confine our inquiries into the effects of war conditions upon such custody. 
When custody has been awarded to the mother it is not materially affected by the father going into service. When the custody of the child has been awarded to the father the child may or may not be in a home maintained by him; in some cases the child is actually with relatives of the father or in an institution. In such cases the father's call into military service may affect the custody in two waysfirst, by some decrease of contact, supervision and direction; second, the child may be left without a legal custodian if the father is a victim of the hazards of war. The second effect stated may be remedied by court action but there is no legal remedy of the first.

There are many cases in which the child is in the father's home when he is called into service. When the home continues to be maintained during his absence, either by his wife or by some relative, the child of divorce continues to have a home but may be left in an unhappy situation with the father away. In those cases in which the home of the father is broken up, such new arrangements as he can make for a home for the child are not always the best for the child's welfare.

In general it seems that in practically all cases of custody of children having been awarded to the father there may be conditions more or less inimical to the child's welfare arising through the father being called into service. The extent to which such a probability should enter into decrees of custody is of course dependent upon a variety of factors. Certainly it cannot be the controlling factor. Also the extent to which it might be to the public interest to exclude from war service the fathers of young children, motherless or otherwise, is a factor. About all that we learn from the information now available and from consideration of all probabilities and factors is that war conditions may adversely affect the welfare of the children of divorced men called into service; that the adverse effects may be greater if the legal custody is vested in the father; that military efficiency is adversely affected when soldiers have the welfare of their children to worry about. No general remedy has been discovered for these conditions and none is proposed. Matters pertaining to custody have their relative importance, but in time of war are certainly less subject to control than are the matters pertaining to financial support to which it is now proposed to turn our attention.

\section{War-Time Legislation}

The provisions of local laws and of orders and decrees thereunder made in time of peace, applicable to the support of dependents of a man later called to service, run headlong into the provisions of national war-time legislation for support of those dependents. This impact discloses some weaknesses in both national and local laws and some possibilities of improvement. It is a sound theory that the courts are the appropriate agencies to consider and determine, under suitable laws, all matters of family relationships, including obligations of support. In the framing of national legislation this principle should be and in fact has been recognized. In the administration of such laws full recognition is generally given to any status 
fixed by local law or a competent court and such is used as a basis for fiscal or other administrative action.

Legislation such as the Servicemen's Dependents Allowance Act of 1942 being national in character very properly seeks to avoid any sectional differences or discriminations in dealing with servicemen and their dependents. There should be no distinctions on account of domicile, residence or citizenship, and from this arise the first difficulties encountered in giving full recognition to the state laws and to the decrees and orders of the state courts. With wide variations in laws and customs, with judicial consideration being given to local economic and social conditions, and with some inconsistencies, appeals and over-ruling within a jurisdiction, there is produced a pattern quite contrary to the desirable uniform basis for administration of the Federal law. For family allowance purposes state law determines whether or not a common-law wife is deemed a lawful wife. A lawful wife may become a divorced wife without her knowledge due to an action in some other jurisdiction accomplished without notice to her. Another lawful wife may continue as such despite some unrecognized action in another jurisdiction. The children of a bigamous marriage may be legitimate in one jurisdiction and illegitimate in another. There is no uniform meaning of such terms as illegitimate, adopted, in loco parentis, etc. Despite all the variations which cause extensive departure from a uniform basis, it has been found administratively expedient and necessary to accept and observe them. Relationships utilized in the granting of family allowances are, therefore, as determined by the laws and judicial procedures of the various states and in some instances of neighboring countries. Of necessity a very considerable burden is imposed in the administration of the law. The status of many dependents must be determined by research into the provisions of various state laws. To determine what law applies in a case, or whether an order or decree is to be observed, is also complicated by the movement of servicemen and of their dependents. When a soldier has a home in one state, his dependent in another, a relationship is established in another and an application for allowances is filed in still another state, determinations present some difficulties. As an example the following "multiple wife" case may be of interest.

The parties to a marriage were residents of New York. The man deserted his wife and later secured a final decree of divorce in Arkansas, service having been by publication. The man returned to New York and for a period lived with his former wife but at a time when common law marriage was not recognized. The man became a serviceman. The wife sued for separate maintenance and the serviceman defended by pleading his Arkansas divorce. The New York court declined to recognize the jurisdiction of the Arkansas court to render the divorce decree and granted the wife's petition. The serviceman subsequently remarried in another jurisdiction. Both wives file application for family allowance and the question is which is to be recognized by the administering agency as the lawful wife entitled to the allowance. Attempt to decide the question carries us all the way up to the 
ruling by the Supreme Court of the United States in the famous case of Williams v. North Carolina, 317 U. S. 287, and even then we have some doubts.

The initial family allowance law contained one exception to the exclusiveness of state decree in determining relationship-an illegitimate child was defined to be one acknowledged by the serviceman under oath to be his child. In a later amendment the provision was changed to require an acknowledgment by the father in writing, not necessarily under oath. The rather strict adherence of the administering departments to state established legal relationhip, particularly in the case of the lawful wife, has been by no means without objection. Under the family allowance law such relationship having been established, allowance is payable whether applied for by the wife or by the soldier. Her financial situation, her earning capacity, or such support as she may or may not have received previously from the husband, are all immaterial; her entitlement to the prescribed amount for her support is presumed and invariable. No sooner was the law in operation than protests of servicemen arose, based primarily on the deductions from their pay for family allowances paid to their wives, to which payments they objected for one reason or another. The reasons in general involved such matters as alleged lack of moral and legal entitlement to support, lack of necessity for support, allegations of misconduct and various impairments and limitations of the marital status. It is clearly a judicial rather than an administrative function to adjudicate such matters. The sound principle of administration based upon judicial determinations of relationship, status, and support, has properly and necessarily been adhered to and all suggestions for administrative determinations have been opposed. The administering agencies could not, even if they tried and were authorized to do so, satisfactorily settle the controversies involved in the protested allowances to wives.

Affording relief from alleged unjust family allowance payments has thus been outside the administrative field and is dependent upon the action of state and local courts. Relief from contributing to a protested allowance to a wife could be had in one of two ways-a legal ending of the status of a lawful wife by divorce without alimony, or a court order or decree.or written separation agreement under which there is a living separate and apart and the instrument provides no amount to be paid to the wife. Needless to say the second method is largely theoretical, such orders or agreements being generally unattainable. The first method, securing a divorce, is one of doubtful advisability as a general practice and has been found to be of limited and variable practicability. Even with a full measure of competent legal assistance being afforded the soldier, the requirements for filing, presentation of evidence, securing service, etc., with many complications as to jurisdiction, have made the securing of divorce very difficult and in some instances impossible.

Some proposals have been made so to amend the family allowance law as to bring about judicial consideration of questions of the legal and moral entitlement of the wife to support, family allowances to wives to be discontinued or modified on the basis of the resulting decrees or court orders. These proposals have gen- 
erally recognized the serious difficulties encountered in bringing and consummating such an action. They have varied as to where an action should be begun and as to continuing or suspending allowances during an action. They have been merely authorizations, recognizing that the timely securing of decrees or orders of such nature cannot be accomplished in many jurisdictions. In most proposals these difficulties have been easily solved by provisions that the whole matter be taken up and adjudicated by the administering department if a court order or decree is not forthcoming within a reasonable time. While it is very gratifying that the various proposals purport to have these vexatious questions judicially resolved and decreed by the courts, it is disturbing that they indicate a realization that procedures under a variety of state laws cannot effectively cope with such a situation. This apparent inability to make adjustments by legal process when the need for adjustment arises in a national emergency, and is reflected in the morale of our military forces, should receive earnest consideration and study.

One suggestion for meeting the problem of protested allowances to wives is to the effect that in any action for divorce the court may, upon application of either party or upon its own motion, at any stage of the proceedings, after due notice and a preliminary hearing upon the merits, enter a temporary order determinative of the portion, if any, of the lawful family allowance that the wife shall receive pending final disposition of the action or proceedings. This proposal is definitely in line with the theory of letting the courts decide the issues of relationship and support. It has an advantage of permitting a solution of the problem of the wife's family allowance without requiring or contemplating the completion of a divorce action. How effective such a proposal would be is problematical. An undetermined factor is the extent and nature of the "preliminary hearing upon the merits." There would, of course, be difficulties in those jurisdictions in which there is considerable rigidity in the initiation or sustaining of an action for divorce. There would be some reluctance to instituting an action for divorce as a vehicle for bringing about a preliminary hearing and a temporary order. It is possible that a way might be found to authorize similar procedure during some legal action other than for divorce.

The initial family allowance law was based upon observance of provisions of decrees and orders of competent courts fixing amounts for alimony or support. The initial provision that family allowance to a former wife divorced not exceed the alimony awarded her in the divorce decree is still retained; so also is the provision that the family allowance to a wife may not exceed an amount fixed in any court order, or decree, or in any written agreement, under which the wife is living separate and apart from the serviceman. In the recent amendment of the family allowance law there was further clarification by a statement that if an instrument is silent, in that it provides no amount to be paid to the wife, no family allowance shall be payable to her. There had been some prior contention that if the instrument fixed no amount the full family allowance would be payable. 
The most interesting provision of the initial family allowance law, and the one that brings us back to problems of children of divorced servicemen, was that which made court orders and decrees for support of children determinative of the amount of family allowances payable to them. Specifically, the provision was that in any case of a child living separate and apart from the enlisted man under a court order or decree or written agreement, the family allowance payable to the child not exceed the amount fixed by the court order or decree or written agreement to be paid to such child. The term "child" was defined in the Act as including an illegitimate child whose support had been decreed or whose paternity had been decreed or acknowledged under oath by the serviceman; however, it was held that court orders or decrees in paternity or illegitimacy proceedings could not be deemed orders which regulate a living separate and apart. The above stated provision of the family allowance law therefore was of no effect in the cases of illegitimate children and family allowances granted to them were for the full amount provided by law for a child or children. Thus the provision of the family allowance law served to restrict the amount of family allowance to the children of divorce and to those covered by a written separation agreement, whereas allowances for all other legitimate children and all illegitimate children were not in any way restricted.

\section{Amending the Servicemen's Dependents Allowance Act}

The experiences of a year in the administration of the Servicemen's Dependents Allowance Act led to several amendments which were enacted in October, 1943. ${ }^{2}$ The general tenor of the amendments was to more adequately provide for children in general. The allowance schedules for all children were raised materially with a view, not only to actual support, but to greater maternal care made possible by the greater aggregate allowances for wife and children. Some increase was provided for parents dependent for their chief support. No increase was provided for the childless wife, the objective being to encourage employment. The amendments completely eliminated, in determining the family allowances for children, any consideration of court orders or decrees specifying the support of children. This elimination of the effect of court orders or decrees was based largely upon three factors: first, the general objective of achieving adequacy and uniformity in children's allowances; second, the great variations and general inadequacies that had been observed in court orders and decrees, in particular the inadequacies in comparison to the family allowance schedules; third, the discriminations among children, incident to the children of unimpaired marriages, motherless children, and even illegitimate children, receiving full allowances. Other factors considered were the problems presented by decrees and orders silent as to support, by orders providing lump sum or property settlements, and by orders providing a total amount without indicating any allocation thereof to the wife and children.

${ }^{2} 57$ STAT. 577 (194I). For complete Act, as amended, see 37 U. S. C. \$\$201-22I (Supp. III, 1941. 1943). 
A variety of situations arose, when allowances were based upon court orders and decrees for support of children, which led to the legislative departure from the general rule of continuing the effect of such orders in granting family allowances. The most common cases were those of amounts in divorce decrees being hopelessly inadequate as family allowances, from the standpoint of providing reasonable support for the children of servicemen. In many cases an inadequate aggregate amount was awarded for the mother and children and when the mother dropped out of the beneficiaries by death or remarriage the amount remaining payable to the children constituted an impossibly small amount for a family allowance for their support. Some decrees were so drawn that all entitlement ceased when the mother remarried, leaving a balance of zero for the children. Many cases arose in which family conditions indicated that payments of the family allowances for the children of the divorced serviceman should be made to someone other than the mother; in fact, in many instances the court orders so stated. This involved divided payments of an inadequate total and under the circumstances it is readily apparent that the small amounts usually included in the divorce decree for the support of children would prove wholly inadequate.

Those decrees in which there was no specification or implication of the amount that was included therein for support of the children were particularly troublesome. The fact that the family allowance for the children could not legally exceed the amount fixed in the court order gave rise to two views; one that when the question of separate payment arose there was no entitlement to family allowance for the children, another that there was no limitation on entitlement to the full allowance for the children. These decrees which prescribed merely that the husband should pay a specified amount weekly or monthly for support of wife and child presented serious difficulties also under circumstances such as the death of the wife or her remarriage.

The unsatisfactory conditions arising when varying provisions of court decrees restricted the amounts of family allowances for children were so generally recognized that there were no objections whatever to the amendment of the law. How far the situation that had developed and the steps that were taken to remedy it may indicate room for improvement in the varieties of law and judicial action is difficult to determine. Neither the laws nor the practices of the courts have been developed with any design of meeting conditions brought about by war and of being a suitable basis for grants of Federal support or payments by the serviceman in time of war. However, when war was imminent or at hand, and when family allowance legislation was in the making, it might have been practicable in many cases for court decrees to take such factors into consideration. In fact, at all times it might be in the interest of all parties and of the state to reasonably anticipate changes in relationships and in conditions bearing upon support in formulating the decrees. A theory that changes will be met by modifying orders has not been demonstrated so far as changes due to war are concerned. 


\section{Criticisms of the Family Allowance Law}

Perhaps a fundamental error was made in the Federal law and no attempt should have been made to apply, in its administration, the orders or decrees of local courts regulating support. In the normal case the family allowance law contemplated that allowances be paid to wives and children according to relationship and without regard to the necessities or other conditions determinative of support. It might have been well to apply this principle to all children, including those of the divorced serviceman: However, there was reluctance to requiring the serviceman to make a contribution toward greater support for children by a divorced wife than the courts had ordered. It was also felt that the huge war-time task of administering family allowances for several million servicemen should be, if possible, on the basis of judicial decrees based upon first-hand information coming to the courts in the course of their proceedings.

An extreme view has been expressed that Federal laws such as the family allow. ance law should, insofar as possible, be wholly Federal and not controlled administratively by state laws or judicial proceedings thereunder. This, it is believed, is an impractical and unwise view. Another extreme view has been that the family allowance or similar law should be completely subordinated to sectional and local conditions, and in particular to all local court adjustments of relationships and obligations. Somewhere between these extremes there is evolved by experience a practicable and suitable Federal law. Our present compromise has been so developed.

There have been other criticisms of the principles of our family allowance law, a major one being that allowances for lawful wives and children are based upon relationship alone and do not take into account any factor of need for support. The basis of the law, which also eliminates application or consent of the serviceman as a condition to granting allowances to wives and children, is the duty and obligation of the husband to support his wife and children. The headaches in administering the law have resulted mostly from the feature of compulsory allowance to the lawful wife and the unqualified assumption of her entitlement to support from the serviceman, supplemented by a generous government contribution. Only by a termination by divorce of her status as lawful wife may her entitlement to allowance be extinguished. Allegations of there having been years of separation without support, of support not being needed because of other income or earning capacity, of promiscuity, lascivious behavior, of infidelity, of a conviction of felony, and all other allegations, are of no avail-the allowance must go on. However, bad as the headaches of administration may be, they do not compare with the situation that would arise through a requirement that in every case there be established a legal and moral right to support, including the degree of necessity. For most wives the legal and moral right exists and is unchallenged; specific establishment thereof would be useless labor. A requirement for establishing need for support would have consequences going far beyond the almost insurmountable administrative 
difficulties. For example, if keeping or taking a well-paying job had possibilities of denying or curtailing the family allowance of the wife and children of the serviceman, the loss of productive power would be tremendous. In comparison the small loss now attributed to the disinclination of some recipients of allowances to work would be infinitesimal, except possibly where taking steady work is a last resort to existence. And, as we know, idleness has other undesirable social effects. Finally it is a certainty that the serviceman in general would condemn any discrimination in the granting of allowances based on accumulated family means, his wife's savings, or upon her employment or earning capacity, or the lack of either.

Other criticisms have been that the allowances are inadequate or that they are too liberal. The latter generally comes from other than the payees in localities in which costs of living are relatively low and there is some disinclination to work except as a last resort. The former generally comes from the urban areas in which living costs are high and usually reflect a view that the allowances should be fully sustaining and not merely contributory. The schedules had the earnest consideration of Congress. They are believed a fair compromise between the extremes and productive of a reasonable average result. Underlying the establishment of schedules there must of course be some thought given to how far a nation may go in providing support for a large element of the citizenry, the effects upon the economic structure, and particularly the effect upon the productivity, essential to our war effort, of all potential workers.

Another criticism of the family allowance law has been the nationwide application of schedules. The counterproposal has been that administration be in the nature of local relief administration. The objections to local administration of support for the families of men in the armed forces of the nation and to the potential variations in treatment of those families, incident to the vagaries in local determinations, are manifest. The very slight dents in morale that have been caused by a few protested payments would, under a system of locally administered and variable support, become wide and disastrous cracks of disaffection extending throughout the armed forces.

It is readily understandable that, with the family allowance law as it is, some of the problems in regard to children may arise with those of undivorced servicemen as well as those of the divorced man. This is particularly true in cases in which the father is seeking or at least feels he has cause for divorce. His protests are generally directed to the allowance to the wife, but, while he does not protest supporting the children, he generally objects to their custody by the mother. His desire to get them away from the mother generally results from a combination of solicitude for their welfare and objection to the mother having any part in receipt or use of the allowances granted on account of the children. In such cases the remedy may lie in legal action to sever the marital relationship, or to establish custody and guardianship for the children, or both. The only administrative action permissible is to designate someone other than the mother as the payee for the 
allowance of a child or children. For manifest reasons this generally follows rather than precedes action removing the children from the mother's custody.

\section{Conclusion}

The problems pertaining to children and other dependents of servicemen that have been discussed are largely those arising through administration of the family allowance law with which the writer has some familiarity. There are of course many more problems, arising in connection with administration of other laws and personal affairs and concerning the activities of juvenile courts, welfare agencies, etc. Taking as broad a view as possible of the war-time problems relative to children of divorced servicemen we find that the probletns are much the same as those pertaining to children of divorce generally, with some aggravated effects of war conditions. In the field of custody many complications and difficulties arise through the father being in or called to service. These serve to emphasize the necessity and importance of measures for custody that will serve directly the interests of the innocent child victim of divorce and indirectly the interests of society.

In the field of support we find an outstanding condition of variability and inadequacy of the provisions of court decrees and orders that has led to an abandonment of their utilization as a basis of war-time family allowances to children of servicemen. We find further a general complicating of administration of war-time family allowances by the diversity of state laws and the practices of courts in defining, establishing and changing relationships and in prescribing support. However, our war-time problems are only one manifestation of the effects of the diversity in local laws and proceedings. The determination of what lesson is to be drawn and what remedy, if any, should be applied must rest upon consideration of a variety of fundamental factors. 